Research paper

\title{
The effects of weathering variability and anthropogenic pressures upon silicon cycling in an intertropical watershed (Tana River, Kenya)
}

\author{
H.J. Hughes a,b,*, S. Bouillon ', L. André ${ }^{\text {a }}$, D. Cardinal a \\ a Dept. of Geology and Mineralogy, Royal Museum for Central Africa, Tervuren, Belgium \\ ${ }^{\mathrm{b}}$ Dept. of Earth and Environmental Sciences, Université Libre de Bruxelles, Brussels, Belgium

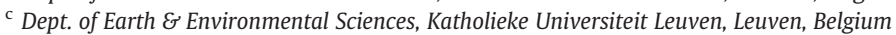

\section{A R T I C L E I N F O}

\section{Article history:}

Received 5 October 2011

Received in revised form 29 February 2012

Accepted 17 March 2012

Available online 23 March 2012

Editor: B. Sherwood Lollar

Keywords:

Tana River

Chemical weathering

Silicon isotopes

Dam impact

Silicon cycle

\begin{abstract}
A B S T R A C T
We present the first study of the Si isotopic composition of dry season river waters from the Tana River Kenya. Data encompasses the entire river basin, with samples collected from headwaters to the estuary, thereby capturing a salinity gradient. In the headwaters, the isotopic signature is affected by climate, as a result of its control on soil drainage and weathering. The $\delta^{30} \mathrm{Si}$ signatures in the basin range from $+0.69 \%$ up to $+2.23 \%$. Signatures are clearly affected by dams: an increase in $\delta^{30} \mathrm{Si}$ ratios of $0.54 \%$ and a decrease in the dissolved $\mathrm{Si}$ (DSi) concentration by $41 \%$ were observed downstream of the Masinga dam, the largest of a succession of 5 hydroelectric dams. This reduction in Si load is most likely due to increased diatom productivity as the corresponding change in $\delta^{30} \mathrm{Si}$ signature is consistent with the known fractionation by these organisms. The $\delta^{30} \mathrm{Si}$ composition of waters entering the estuary is ca. $+2 \%$ and DSi concentrations are $349 \mu \mathrm{M}$. In the estuary, the DSi concentrations decrease linearly following the salinity, while the $\delta^{30} \mathrm{Si}$ ratio remains stable, indicating the absence of processes affecting the DSi pool for the studied range of salinity.
\end{abstract}

(c) 2012 Elsevier B.V. All rights reserved.

\section{Introduction}

The weathering of silicate rocks is the primary source of silicon ( $\mathrm{Si}$ ), a major chemical element in most rivers and a key element for life. Chemical weathering and the concomitant release of $\mathrm{Si}$ in its dissolved form ( silicic acid, $\mathrm{H}_{4} \mathrm{SiO}_{4}$, thereinafter referred to as $\mathrm{DSi}$ ) to the hydrosphere are controlled by different parameters, including lithology (Bluth and Kump, 1994; Beusen et al., 2009), climate (Kump et al., 2000; Dessert et al., 2003), gradient of terrain and vegetation cover (Berner, 1997; Beusen et al., 2009; Roelandt et al., 2010). Once in its dissolved form, Si becomes available for biological uptake by higher plants and by diatoms (an important component of phytoplankton) to form biogenic silica (opal, $\mathrm{SiO} \cdot \cdot \mathrm{nH}_{2} \mathrm{O}$, thereinafter referred to as $\mathrm{BSi}$ ). However, despite its importance as a nutrient and in continental geochemistry, the major environmental variables controlling the continental Si cycle remain poorly constrained in comparison with other elements like P, C and N (Garnier et al., 2006; Cornelis et al., 2011). Moreover, despite the fact that direct anthropogenic inputs of DSi are generally considered to be limited, indirect human impacts through deforestation, dam construction or agriculture can widely affect DSi fluxes to rivers (Humborg et al., 2006; Conley et al., 2008; Struyf et al., 2010). River damming, for example, increases water residence time and

\footnotetext{
* Corresponding author at: Royal Museum for Central Africa, Leuvensesteenweg, 13 B-3080 Tervuren, Belgium. Tel.: + 32276954 01; fax: + 3227695432 .

E-mail address: harold.hughes@africamuseum.be (H.J. Hughes).
}

creates favorable conditions for the development of diatoms, which will consume DSi, converting it to BSi. Their subsequent sedimentation constitutes another export of Si in the form of buried BSi (e.g., Conley et al., 2000; Laruelle et al., 2009).

In the last decade, stable isotopes of Si have been increasingly used as a tracer for Si fluxes and cycling, especially in marine environments and soils. However, little is known about the mechanisms controlling the variability of $\delta^{30} \mathrm{Si}$ in rivers. It has been shown that, in most rivers, the DSi is enriched in heavy isotopes, relative to rocks, which are the primary reservoir of Si. Indeed, known $\delta^{30} \mathrm{Si}$ signatures of rivers range from $-0.1 \%$ up to $+3.4 \%$ (Ding et al., 2004; Georg et al., 2007). This contrasts strongly with the mean $\delta^{30} \mathrm{Si}$ values of mantle-derived rocks $(-0.29 \pm 0.08 \%$; Savage et al., 2010$)$ or crustal derived components ( $\sim \%$; Ding et al., 1996; André et al., 2006). This positive $\delta^{30} \mathrm{Si}$ signature in the freshwater hydrosphere is the result of several fractionation processes. Firstly, during weathering of primary minerals, lighter isotopes are preferentially incorporated in neoformed clay minerals, such as kaolinite and smectite, whose known $\delta^{30} \mathrm{Si}$ signatures range from $-2.95 \%$ o up to $-0.16 \%$ o (e.g., Ziegler et al., 2005a; Georg et al., 2009; Opfergelt et al., 2010), and several studies have shown that $\delta^{30} \mathrm{Si}$ values in soil material become lighter with ageing due to the increasing proportion of neoformed clay minerals (Ziegler et al., 2005a; Opfergelt et al., 2008, 2010). Secondly, Si uptake by higher plants (Opfergelt et al., 2006; Hodson et al., 2008) and by diatoms (De La Rocha et al. 1997) also tends to discriminate against heavier isotopes. In plants, an isotopic fractionation occurs at the 
solution-roots interface $\left({ }^{30} \varepsilon=-0.78 \%\right.$ omeasured in banana trees; Opfergelt et al., 2006) and in addition, an intra-plant fractionation also occurs; the range of $\delta^{30} \mathrm{Si}$ ratios observed for plant phytoliths therefore goes from $-2.3 \%$ o to $+6.1 \%$ 。 (Ding et al., 2005, 2008). Continental diatoms show a fractionation factor of ${ }^{30} \varepsilon=-1.1 \%$ o (see discussion below). Si adsorption onto iron oxides has also been shown to discriminate against heavier isotopes (fractionation factors of ${ }^{30} \varepsilon=$ $-1.56 \%$ of gor goethite and $-1.05 \%$ ofor ferrihydrite, Delstanche et al., 2009; Opfergelt et al., 2009), however little is known about the relative importance of this process in the global Si cycle.

Recently, Si isotopes have been used in small watersheds as a tracer for weathering processes (e.g., Georg et al., 2007; Opfergelt et al., 2008), but also in the Congo River where it was used to trace weathering rates and mixing processes (Cardinal et al., 2010) and diatom production (Hughes et al., 2011). Changes in the riverine delivery of DSi can also have a high impact on the diatom productivity of the coastal zone (Laruelle et al., 2009). However, Si isotopes in estuaries have so far been totally overlooked - apart from one data point in the Yangtze River (Ding et al., 2004). Since many processes can affect the Si distribution in estuaries and coastal zones (e.g., diatom uptake or abiotic processes such as BSi dissolution, DSi adsorption and reverse weathering) it is interesting to study their impact on $\delta^{30} \mathrm{Si}$ signatures.

In this study, patterns in $\delta^{30} \mathrm{Si}$ signatures are presented for an intertropical river basin (Tana River, Kenya), from its headwater regions to the ocean. As this is the first study exploring $\delta^{30} \mathrm{Si}$ variations at the scale of an entire river network and the estuarine salinity gradient, we aimed at identifying the main parameters influencing the $\delta^{30} \mathrm{Si}$ signature of DSi - including the role of dams - in order to improve the use of $\delta^{30} \mathrm{Si}$ ratio as a tracer of $\mathrm{Si}$ fluxes and cycling in riverine environments.

\section{General study area settings}

The Tana River is a tropical river flowing in a watershed largely dominated by semi-arid climate that drains into the Indian Ocean (Fig. 1). It is the longest river system in Kenya, with a catchment area of $\sim 120,000 \mathrm{~km}^{2}$ (Kitheka et al., 2005). An average of $4.3 \times 10^{9} \mathrm{~m}^{3}$ of freshwater is discharged annually, with peak flows occurring between April and June and a shorter high flow period in November and December (Maingi and Marsh, 2002). The Tana River drains mainly tertiary and quaternary volcanic rocks. The soil erosion rate is high due to the steep slopes, agriculture and sparse vegetation cover (Dunne, 1979; Brown et al., 1996; Schneider et al., 1999). Its three main headwaters are located in high-altitude regions, the southern and eastern slopes of Mount Kenya, the Aberdare Range, and the Nyambene Range (Fig. 1).

Mount Kenya is one of the main volcanoes to the east of the rift and its active period dates back to the late Pliocene (2 to $3.5 \mathrm{Ma}$ ) but probably extended into the Pleistocene. It is mainly built of phonolites, kenytes and trachytes with late basalts (King and Chapman, 1972). Its slopes are largely used for agriculture. The Aberdare Range rises to a height of over $4000 \mathrm{~m}$ and consists mainly of basalts with overlying phonolites, basalts and mugearites. The vegetation in the upper ranges of the Aberdares (above $3000 \mathrm{~m}$ ) consists of bamboo and montane rainforests. The Nyambene Range is a shield volcano capped by cumulodomes and basaltic cones and lava flows of late-Pleistocene to Holocene age (Baker, 1967). Vegetation here varies from open to closed-canopy savannah grasslands. At the southeastern margin of the Mount Kenya volcanic field, outcroppings of metamorphic gneisses and schists of the pre-Cambrian basement appear (Baker, 1967). Here, the river flows through a succession of 5 hydroelectric dams. The largest barrier lake at the Masinga dam $\left(\sim 120 \mathrm{~km}^{2}\right)$ acts as a storage reservoir for the four other dams downstream (Uku and Mavuti, 1994). This lake has an estimated mean water residence time of $\sim 3$ months. This substantial residence time causes the majority of sediments to settle (see e.g., Pacini et al., 1999; and references therein), increasing light penetration in the photic zone and thereby permitting increased phytoplankton production. Consequently, these dams induce a strong nutrient retention (Pacini et al., 1999) and a decrease of $41 \%$ in Si concentration has been observed between pre- and post-Masinga reservoir water (Bouillon et al., 2009). This steep decrease of the DSi concentration is consistent with the observations from Uku and Mavuti (1994) showing

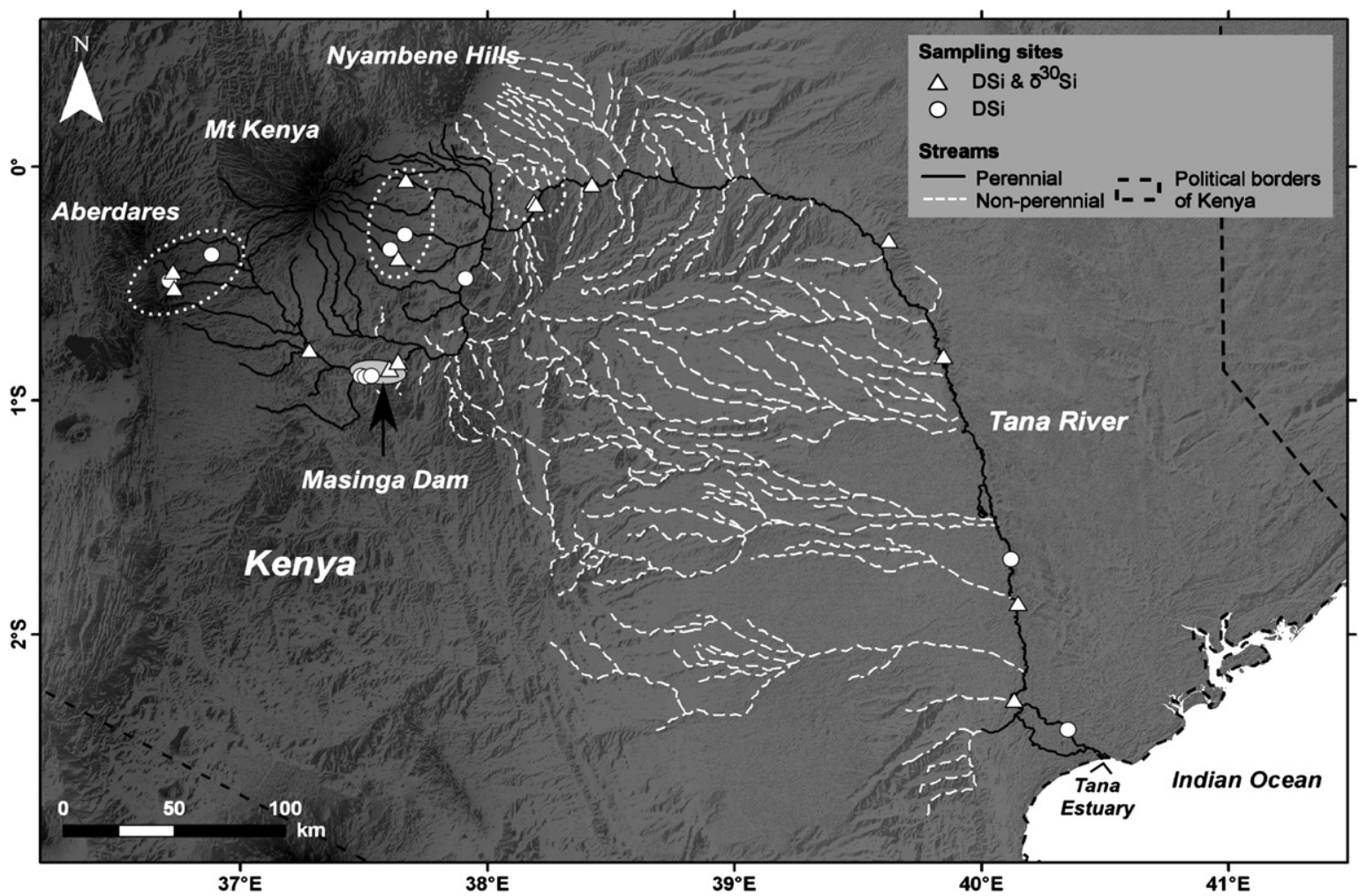

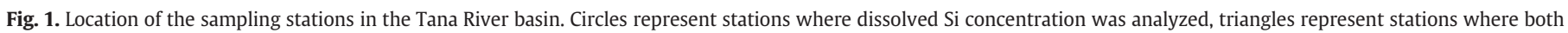
the concentration and the $\delta^{30} \mathrm{Si}$ ratio were analyzed. 
the predominance of the diatom genus Nitzschia in the phytoplankton composition in the Masinga reservoir.

Downstream of the dams, a long section of the lower river, from the Nyambene Range sampling site down to the estuary, meanders through a semi-arid alluvial plain, fringed by a narrow band of evergreen riverine forest. Here, the Precambrian basement is covered by thin infertile and erodible soils (Uku and Mavuti, 1994). This part of the river does not receive any inputs from tributaries during the dry season (Hughes, 1984). After this reach, the river flows into the Ungwana Bay and the Indian Ocean mostly via the Tana estuary; a smaller part flows through the Tana Delta southwest of the estuary. Tides are semi-diurnal and the mean residence time in the estuary is estimated to be in the order of 3 days (Kitheka et al., 2005).

\section{Methods}

\subsection{Sampling}

The estuarine samples were collected in mid-April 2004 in the estuary and its plume along a salinity gradient from 0 up to 28.8 at 20 stations (see Bouillon et al., 2007 for a comprehensive description of the sampling). River sampling was conducted in February 2008 during the dry season (period of low river flow from January to March). Riverine samples were collected at 25 sites, of which 12 stations included samples for Si isotope measurements. Six of the latter were taken in streams that are unaffected by dams, the others come from the surface of the main reservoir lake (Masinga) and from downstream of the dams, in the main stem of the river. Samples were taken at $\sim 0.5 \mathrm{~m}$ below the water surface and whenever possible for riverine samples, in the middle of the stream (see Bouillon et al., 2009). Samples collected specifically for $\delta^{30} \mathrm{Si}$ analyses were immediately filtered through a $0.45 \mu \mathrm{m}$ polyethersulfone (PES) or polycarbonate (PC) filter and kept in rinsed polypropylene (PP) bottles. Note that isotopic signatures were also analyzed in two riverine samples (R-6 and R-15) that were not initially collected for $\mathrm{Si}$ isotopic measurements and which were filtered on a Whatman GF/F filter. Subsequent artifacts in the measured dissolved Si concentrations are however unlikely, given the high DSi concentrations of these samples and the fact that, for samples collected specifically for $\delta^{30} \mathrm{Si}$ analyses, no systematic difference in DSi concentrations could be observed between samples filtered on GF/F filters and aliquots filtered on PC or PES filters (Bouillon et al., 2009).

\subsection{Element analyses}

DSi concentration was measured by the colorimetric method. In the samples from the headwater regions, concentrations of major cations $\left(\mathrm{Na}^{+}, \mathrm{K}^{+}, \mathrm{Ca}^{2+}\right.$, and $\mathrm{Mg}^{2+}$ ) were measured by ICP-AES (Iris Advantage, Thermo Jarrel-Ash) and $\mathrm{Cl}^{-}$concentrations were measured by ion chromatography (ICS-900, Dionex). Major cation concentrations in the headwater regions can be corrected for input of atmospheric salts. This is necessary in order to estimate $\mathrm{Si} / \Sigma \mathrm{C}^{+*}$, the ratio between $\mathrm{Si}$ contents and cations contents deriving from weathering only, with $\mathrm{SC}^{+*}$ being the sum of the major cations corrected for input of atmospheric salts. Atmospheric inputs were estimated assuming that all the $\mathrm{Cl}^{-}$from the dissolved loads of the rivers derives from precipitation and that these atmospheric inputs retain the same ratio to $\mathrm{Cl}^{-}$as in seawater (Dunne, 1978). Calculated atmospheric inputs were then subtracted from the measured cation concentrations in the stream water in order to obtain the concentration derived from continental sources. Note that DSi concentrations were also measured by ICP-AES and were consistent with results obtained with the colorimetric method, indicating that there is no contamination of the samples by ultra-fine clays. Biogenic silica content in the river water could not be measured due to the very high amount of suspended lithogenic particles.

\subsection{Isotopic analyses}

For samples taken for $\delta^{30} \mathrm{Si}$ analyses, DSi was purified using the triethylamine molybdate (TEA-moly) co-precipitation method and combustion in covered Pt crucibles at $1000{ }^{\circ} \mathrm{C}$ (De La Rocha et al., 1996). Purified samples were then dissolved in a dilute Suprapur $\mathrm{HF}-\mathrm{HCl}$ mixture (Cardinal et al., 2003). Si isotopic ratios were measured with a Nu Plasma Multi-Collector-ICP-MS (Nu Instruments, UK) at the Université Libre de Bruxelles, Brussels, operating in dry plasma mode with a Cetac Aridus II desolvating nebulization system. Mass bias was corrected with an external Mg doping (Cardinal et al., 2003), while the long-term instrumental drift was corrected by the standard-sample bracketing technique relative to the NBS28 silica sand standard (NIST, SRM No. 8546) or an in house standard (pro analysi Quartz from Merck). Data acquisition was done in medium resolution mode. The isobaric interference of ${ }^{14} \mathrm{~N}^{16} \mathrm{O}$ on the ${ }^{30} \mathrm{Si}$ peak was resolved by analyzing the interference-free low-mass side of the ${ }^{30} \mathrm{Si}$ peak ("pseudo high resolution", Abraham et al., 2008). The accuracy of the $\delta^{30} \mathrm{Si}$ measurements was checked on a daily basis by measuring a secondary reference material (Diatomite; Reynolds et al., 2007). The long-term average analytical reproducibility and accuracy on reference material for $\delta^{30}$ Si were of $\pm 0.07 \%$ 。 $\left( \pm 1 \sigma_{\mathrm{SD}}\right)$. All samples but one have been fully replicated at least once (chemical separation plus measurements). All results are expressed as $\delta^{30} \mathrm{Si}(\%)$ relative to NBS28 as:

$\delta^{30} \mathrm{Si}=\left[\frac{\left({ }^{30} \mathrm{Si} /{ }^{28} \mathrm{Si}\right)_{\text {sample }}}{\left({ }^{30} \mathrm{Si} /{ }^{28} \mathrm{Si}\right)_{\mathrm{NBS} 28}}-1\right] \times 1000$

\subsection{Rainfall}

Effective rainfall, which corresponds to rainfall minus evapotranspiration, was estimated for each sampling sites of the headwater regions, during the period of fieldwork in February 2008. This was conducted using the New_LocClim software from FAO (Grieser et al., 2006). This software was used in order to provide average monthly values for rainfall and evapotranspiration at the sampling sites, based on extrapolation from a FAO agroclimatic database using the kriging interpolation method and a standard altitude correction. As the annual evapotranspiration exceeds the total annual rainfall in the region, it is common to observe negative values for monthly effective rainfall.

\section{Results}

The DSi concentration varied widely over the Tana basin (Table 1). In the headwater regions, values ranged from $164 \mu \mathrm{M}$ to $959 \mu \mathrm{M}$, the highest concentrations being found in the Nyambene mountain range. Bouillon et al. (2009) have highlighted that DSi concentrations of water are greatly decreased when flowing through catchment storage reservoirs. The Sagana, the main tributary of the Masinga reservoir, has a DSi concentration of $364 \mu \mathrm{M}$ while it is of $208 \mu \mathrm{M}$ for the surface water of the Masinga reservoir. Downstream of the dams, DSi concentrations in the main Tana River were similarly low $(215 \mu \mathrm{M}$, which corresponds to a decrease of $41 \%$ between the Sagana and the post-dams river reaches), and did not exceed $314 \mu \mathrm{M}$ further downstream. In the lower part of the river, all tributaries downstream of the Nyambene Range sampling site were dry during the sampling period so that no more freshwater entered the river before the estuary. The DSi concentration of the river waters after this area remained fairly constant between $307 \mu \mathrm{M}$ and $314 \mu \mathrm{M}$ for the 2008 sampling period. Water temperature, calculated effective rainfall for the sampling month (February 2008) and annual effective rainfall in the headwaters, are strongly linked to the altitude of the sampling site ( $\mathrm{R}^{2}$ of $0.86,0.99$, and 0.63 , respectively).

The isotopic Si signatures in the Tana River lie within the previously reported global range for river waters. $\delta^{30} \mathrm{Si}$ values in the headwater 
Table 1

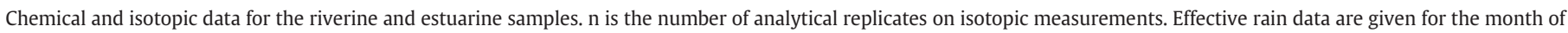
February. Where only one isotopic analysis could be done the long-term average analytical reproducibility on reference material is given (italic value).

\begin{tabular}{|c|c|c|c|c|c|c|c|c|c|c|c|c|c|c|c|c|c|}
\hline \multirow[t]{2}{*}{ Sample } & \multirow[t]{2}{*}{ Location } & \multirow{2}{*}{$\frac{{ }^{\circ} \mathrm{S}}{\text { Decimal }}$} & \multirow{2}{*}{$\frac{{ }^{\circ} \mathrm{E}}{\text { Decimal }}$} & \multirow{2}{*}{$\frac{\text { Useful rain }}{\mathrm{mm} / \mathrm{month}}$} & \multirow{2}{*}{$\frac{\text { Altitude }}{\mathrm{m}}$} & \multirow{2}{*}{$\frac{\mathrm{DSi}}{\mu \mathrm{M}}$} & \multirow{2}{*}{$\frac{\mathrm{Ca}}{\mu \mathrm{M}}$} & \multirow{2}{*}{$\frac{\mathrm{Mg}}{\mu \mathrm{M}}$} & \multirow{2}{*}{$\frac{\mathrm{Na}}{\mu \mathrm{M}}$} & \multirow{2}{*}{$\frac{\mathrm{K}}{\mu \mathrm{M}}$} & \multirow{2}{*}{$\frac{\mathrm{Cl}}{\mu \mathrm{M}}$} & \multirow[t]{2}{*}{$\mathrm{Si} / \sum \mathrm{C}^{+*}$} & \multirow{2}{*}{$\frac{\delta^{30} \mathrm{Si}}{\% 。}$} & $2 \sigma_{\mathrm{SD}}$ & $\delta^{29} \mathrm{Si}$ & $2 \sigma_{\mathrm{SD}}$ & $\mathrm{n}$ \\
\hline & & & & & & & & & & & & & & & $\%$ & & \\
\hline Headwaters & Aberdares & & & & & & & & & & & & & & & & \\
\hline $\mathrm{R}-1$ & Muringato River & 0.3746 & 36.8838 & & 2010 & 376 & 94 & 53 & 217 & 84 & 71 & 0.99 & & & & & \\
\hline $\mathrm{R}-2$ & Chania River & 0.4542 & 36.7161 & 34 & 3020 & 270 & 103 & 62 & 127 & 26 & 14 & 0.89 & 1.15 & 0.17 & 0.57 & 0.06 & 2 \\
\hline R-3 & Maguru River & 0.4869 & 36.7080 & & 3010 & 164 & 24 & 17 & 57 & 18 & 25 & 1.80 & & & & & \\
\hline $\mathrm{R}-4$ & $\begin{array}{l}\text { Karuru, upstream of falls } \\
\text { Nyambeni Hills }\end{array}$ & 0.5243 & 36.7215 & 21 & 2940 & 165 & 28 & 19 & 51 & 17 & 14 & 1.62 & 0.69 & 0.03 & 0.30 & 0.04 & 3 \\
\hline $\mathrm{R}-12$ & Mutundu River & 0.1646 & 38.1877 & -136 & 620 & 959 & 876 & 826 & 1473 & 259 & 97 & 0.29 & 1.53 & 0.11 & 0.77 & 0.01 & 2 \\
\hline $\mathrm{R}-13$ & $\begin{array}{l}\text { Rojewero River } \\
\text { Mount Kenya Slope }\end{array}$ & 0.1545 & 38.1808 & -137 & 610 & 829 & 313 & 306 & 1204 & 156 & 113 & 0.44 & 1.71 & 0.25 & 0.88 & 0.05 & 4 \\
\hline R-15 & Thingithu River & 0.0615 & 37.6601 & -76 & 1500 & 587 & 83 & 54 & 615 & 93 & 75 & 0.76 & 1.32 & 0.04 & 0.58 & 0.04 & 2 \\
\hline R-16 & Mara River & 0.2142 & 37.6571 & & 1350 & 365 & 29 & 19 & 354 & 37 & 58 & 0.95 & & & & & \\
\hline R-17 & Nithi River & 0.2873 & 37.6651 & & 1400 & 434 & 37 & 37 & 917 & 66 & & & & & & & \\
\hline $\mathrm{R}-18$ & Ruguti River & 0.3542 & 37.6078 & & 1590 & 251 & 38 & 36 & 653 & 64 & & & & & & & \\
\hline $\mathrm{R}-19$ & Thuchi River & 0.3950 & 37.6284 & -86 & 1440 & 250 & 29 & 24 & 437 & 51 & 56 & 0.52 & 1.35 & 0.02 & 0.63 & 0.03 & 2 \\
\hline Masinga Dam & & & & & & & & & & & & & & & & & \\
\hline $\mathrm{R}-7$ & Masinga reservoir & 0.8894 & 37.6402 & & 1050 & 208 & 240 & 133 & 305 & 32 & & & 2.23 & 0.15 & 1.16 & 0.04 & 2 \\
\hline $\mathrm{R}-8$ & Masinga reservoir & 0.8939 & 37.5313 & & 1050 & 207 & 168 & 99 & 220 & 23 & & & & & & & \\
\hline R-9 & Masinga reservoir & 0.8987 & 37.5053 & & 1050 & 208 & 215 & 143 & 339 & 34 & & & & & & & \\
\hline $\mathrm{R}-10$ & Masinga reservoir & 0.8940 & 37.4878 & & 1050 & 209 & 237 & 146 & 325 & 32 & & & & & & & \\
\hline Main Tana Ri & ver & & & & & & & & & & & & & & & & \\
\hline $\mathrm{R}-5$ & $\begin{array}{l}\text { Sagana River, } 5 \mathrm{~km} \text { before } \\
\text { Masinga dam }\end{array}$ & 0.7874 & 37.2689 & -124 & 1110 & 364 & 239 & 207 & 296 & 33 & 147 & 0.57 & 1.55 & 0.10 & 0.75 & 0.12 & 2 \\
\hline R-6 & $\begin{array}{l}\text { Tana River just downstream } \\
\text { Masinga }\end{array}$ & 0.8738 & 37.5915 & & 1020 & 215 & 221 & 145 & 327 & 35 & & & 2.09 & 0.15 & 1.07 & 0.10 & 3 \\
\hline $\mathrm{R}-11$ & $\begin{array}{l}\text { Tana River between Masinga } \\
\text { and Katse }\end{array}$ & 0.4740 & 37.9126 & & 550 & 244 & 270 & 175 & 450 & 46 & & & & & & & \\
\hline $\mathrm{R}-14$ & Tana River at Kora Nat. Park & 0.0777 & 38.4147 & & 350 & 289 & 281 & 153 & 425 & 42 & & & 1.86 & 0.22 & 0.97 & 0.09 & 3 \\
\hline $\mathrm{R}-20$ & Tana River, Sankuri & 0.3203 & 39.5617 & & 150 & 309 & 311 & 188 & 580 & 62 & & & 1.70 & 0.08 & 0.87 & 0.06 & 2 \\
\hline $\mathrm{R}-21$ & Tana River, Nanigi & 0.8172 & 39.8394 & & 110 & 307 & 353 & 181 & 571 & 61 & & & 1.79 & 0.19 & 0.92 & 0.05 & 5 \\
\hline $\mathrm{R}-22$ & Tana River, Masalani & 1.6773 & 40.1195 & & 50 & 314 & 362 & 187 & 633 & 68 & & & & & & & \\
\hline $\mathrm{R}-23$ & $\begin{array}{l}\text { Tana River, Tana River primate } \\
\text { reserve }\end{array}$ & 1.8759 & 40.1409 & & 36 & 313 & 361 & 164 & 571 & 58 & & & 1.78 & 0.18 & 0.91 & 0.04 & 3 \\
\hline $\mathrm{R}-24$ & Tana River, Garsen & 2.2889 & 40.1266 & & 18 & 312 & 388 & 198 & 665 & 71 & & & 1.87 & 0.10 & 0.95 & 0.03 & 2 \\
\hline $\mathrm{R}-25$ & $\begin{array}{l}\text { Tana River (Matombe branch), } \\
\text { Chalaluma }\end{array}$ & 2.4098 & 40.3518 & & 8 & 305 & 394 & 186 & 645 & 63 & & & & & & & \\
\hline Estuary & & & & Salinity & & & & & & & & & & & & & \\
\hline E-25 & & 2.5240 & 40.4711 & 0 & & 356 & & & & & & & & & & & \\
\hline $\mathrm{E}-27$ & & 2.4986 & 40.4639 & 0 & & 353 & & & & & & & 2.05 & 0.14 & 1.05 & 0.07 & 1 \\
\hline E-26 & & 2.5094 & 40.4783 & 0 & & 348 & & & & & & & & & & & \\
\hline E-6 & & 2.5194 & 40.4683 & 0 & & 344 & & & & & & & & & & & \\
\hline E-5 & & 2.5236 & 40.4803 & 0 & & 346 & & & & & & & & & & & \\
\hline E-4 & & 2.5164 & 40.4939 & 0.3 & & 344 & & & & & & & & & & & \\
\hline E-1 & & 2.5400 & 40.5361 & 0.6 & & 343 & & & & & & & & & & & \\
\hline E-3 & & 2.5189 & 40.5061 & 1.4 & & 345 & & & & & & & & & & & \\
\hline E-9 & & 2.5258 & 40.5169 & 1.8 & & 337 & & & & & & & 2.01 & 0.14 & 1.06 & 0.04 & 2 \\
\hline $\mathrm{E}-24$ & & 2.5197 & 40.5069 & 4.1 & & 342 & & & & & & & 2.08 & 0.16 & 1.06 & 0.01 & 4 \\
\hline E-16 & & 2.5331 & 40.5322 & 4.8 & & 321 & & & & & & & 2.08 & 0.14 & 1.11 & 0.02 & 2 \\
\hline E-14 & & 2.5447 & 40.5464 & 9.2 & & 272 & & & & & & & 2.01 & 0.14 & 1.09 & 0.16 & 2 \\
\hline $\mathrm{E}-20$ & & 2.5436 & 40.5219 & 13.1 & & 226 & & & & & & & & & & & \\
\hline E-11 & & 2.5536 & 40.5364 & 14.2 & & 234 & & & & & & & 2.12 & 0.14 & 1.06 & 0.03 & 2 \\
\hline E-13 & & 2.5478 & 40.5489 & 15.4 & & 224 & & & & & & & 1.99 & 0.25 & 1.02 & 0.10 & 4 \\
\hline $\mathrm{E}-21$ & & 2.5486 & 40.5231 & 16.9 & & 192 & & & & & & & & & & & \\
\hline E-12 & & 2.5581 & 40.5364 & 18.3 & & 192 & & & & & & & & & & & \\
\hline $\mathrm{E}-22$ & & 2.5506 & 40.5244 & 24.3 & & 121 & & & & & & & 1.85 & 0.14 & 0.98 & 0.04 & 2 \\
\hline E-15 & & 2.5483 & 40.5431 & 24.9 & & 120 & & & & & & & 1.85 & 0.18 & 1.05 & 0.05 & 4 \\
\hline $\mathrm{E}-23$ & & 2.5503 & 40.5311 & 28.8 & & 68 & & & & & & & 1.99 & 0.14 & 1.02 & 0.13 & 3 \\
\hline
\end{tabular}

regions ranged from $+0.69 \%$ o to $+1.71 \%$. A high isotopic value of $+2.23 \%$ is observed in the surface water of the Masinga reservoir. However, in the lower reach of the river, $\delta^{30} \mathrm{Si}$ ratios remain fairly constant with a mean value of $+1.80 \pm 0.07 \%$ o $\left( \pm 1 \sigma_{\mathrm{SD}}, \mathrm{n}=5\right)$. Among the freshwater samples, two marked trends are observed (Fig. 2). For the samples from the headwater regions, a linear inverse correlation exists between the ${ }^{30}$ Si values and $1 / D S i\left(R^{2}=0.77 ; n=7 ; p<0.01\right)$. Isotopic signatures of this group are also strongly anti-correlated with climatic parameters such as the estimated effective rainfall in February $\left(R^{2}=0.77 ; n=7 ; p<0.01\right.$; Fig. $\left.3 A\right)$, and water temperature $\left(R^{2}=0.74\right.$; $\mathrm{n}=7 ; \mathrm{p}<0.02)$. A strong correlation is also noticed between the $\delta^{30} \mathrm{Si}$ ratio and $\mathrm{Si} / \Sigma \mathrm{C}^{+*}$, the molar proportion of $\mathrm{Si}$ relative to the sum of main dissolved cations ( $\mathrm{R}^{2}=0.89 ; \mathrm{n}=7 ; \mathrm{p}<0.002$; Fig. 3B). The second important trend is seen in the surface water samples of the Masinga reservoir, those collected downstream of the dams, and the Sagana River, main tributary of the reservoir $\left(R^{2}=0.92 ; n=8 ; p=10^{-4}\right.$, Fig. 2$)$.

In the samples collected from the estuary, the DSi concentration in the freshwater end-member was $349 \pm 5 \mu \mathrm{M}\left( \pm 1 \sigma_{\mathrm{SD}}, \mathrm{n}=5\right)$ and decreased to $68 \mu \mathrm{M}$ Si at a salinity of 28.8 (Fig. 4A). The DSi concentrations and the $\delta^{30} \mathrm{Si}$ signature measured for the freshwater end-member are 


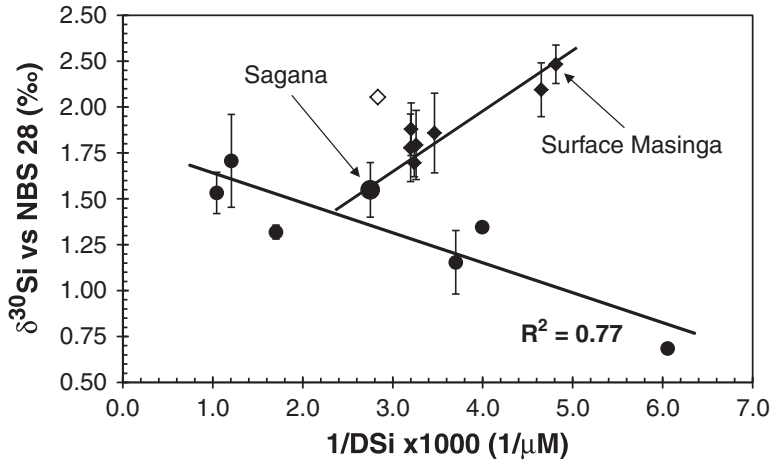

Fig. 2. Isotopic signatures in riverine samples from the headwaters (circles), including the Sagana, are anti-correlated with 1/DSi. Isotopic signatures from the samples of 2008 collected downstream the dams and at the surface of the Masinga reservoir (black diamonds) correlate with 1/DSi, which is consistent with an uptake of DSi by diatoms in the reservoir and with the Sagana as the main source of DSi for the reservoir. The freshwater sample from the estuarine sampling of 2004 (empty diamond) presents both higher DSi content and $\delta^{30}$ Si ratio than the most downstream samples from 2008 this simultaneous increase of both parameter is consistent with the observations in the headwater regions. Error bars are $2 \sigma_{\mathrm{SD}}$ on the $\delta^{30} \mathrm{Si}$ ratio.

slightly higher than the most downstream sample from 2008 (increase of $+45 \mu \mathrm{M}$ and $+0.18 \%$, respectively). Along the estuary, the decrease in the DSi concentration linearly follows the salinity gradient $\left(R^{2}=0.98\right)$, suggesting a conservative behavior. In only two samples (E23 and E24 at salinity of 4.1 and 28.8, respectively) DSi concentrations slightly differ from those expected on the basis of this linear relationship (Fig. 4A). The $\delta^{30} \mathrm{Si}$ values in the estuary also remain relatively constant with a mean value of $+1.99 \pm 0.09 \%$ 。 $\left( \pm 1 \sigma_{\mathrm{SD}}, \mathrm{n}=10\right)$ and a maximum range of $0.27 \%$ (Fig. 4B). Note that our DSi data for the estuarine samples differ significantly from those published earlier by Bouillon et al. (2007). But since we obtain a close to perfect linear

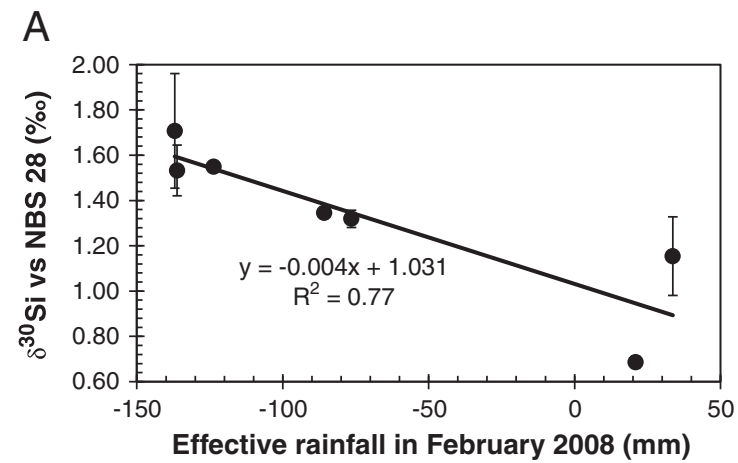

B

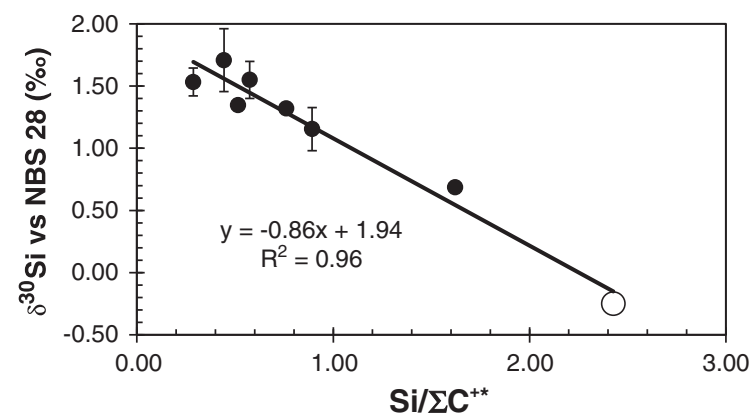

Fig. 3. (A) Inverse correlation in the headwater samples between the isotopic signature and the effective rainfall during the sampling period estimated using the New_LocClim database. (B) Inverse correlation between the isotopic signature and the $\mathrm{Si} / \mathrm{\Sigma C}^{+*}$ ratio (with $\mathrm{LC}^{+*}$ as the sum of cations corrected for the input of atmospheric) in samples from the headwaters (black dots) and in the estimated source rock (empty circle). The linear trend is consistent with an evolution from a common Si source. Error bars are $2 \sigma_{\mathrm{SD}}$ on the $\delta^{30} \mathrm{Si}$ ratio.
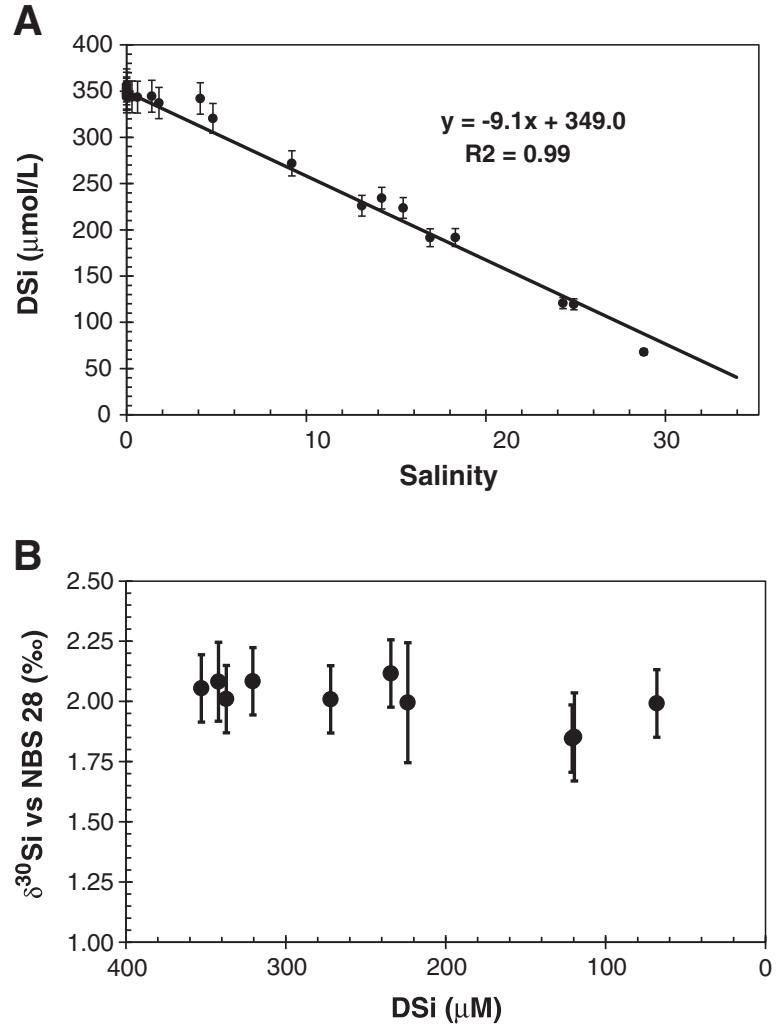

Fig. 4. (A) Evolution of the dissolved Si concentration in the Tana Estuary along the salinity gradient. The DSi behaves mostly conservatively; DSi concentrations slightly differ from those expected on the basis of a linear regression only in two samples (at salinities 4.1 and 28.8). (B) Evolution of the $\delta^{30} \mathrm{Si}$ signature in the estuary along the DSi concentration gradient (note the reverse scale). Error bars are $2 \sigma_{\mathrm{SD}}$ on the $\delta^{30} \mathrm{Si}$ ratio.

relationship between DSi and salinity, it appears that the earlier estuarine DSi data (Bouillon et al., 2007), are inaccurate for an unknown reason.

\section{Discussion}

As displayed in Fig. 2, the dam has a clear effect upon the Si cycle in the Tana watershed. The discussion of the results will therefore be subdivided in three sections, looking at i) the headwaters, ii) the Masinga reservoir and the lower Tana River (downstream of the dams) and iii) the estuary.

\subsection{Headwater regions}

The high DSi concentrations observed in some of the tributaries (in particular the area of the Nyambene Hills) most likely arises from the presence of ashes and pyroclastic rocks, which have much higher weathering rates than basalts and trachytes (Speck, 1982). The very strong inverse correlation that we observe between $\delta^{30} \mathrm{Si}$ signatures and 1/DSi for the samples from the headwater regions (Fig. 2) may seem counter-intuitive at first, as most of the processes removing DSi from solution tend to simultaneously enrich the solution in heavy isotopes. However, a positive relationship between the DSi concentrations and the isotopic signatures in rivers is often observed (e.g., De La Rocha et al., 2000; Alleman et al., 2005; Georg et al., 2006). Georg et al. (2006) interpreted this trend as the result of the mixing of two components: a) basal flow (seepage from soil and/or ground water), with low weathering flux, high solute concentration and a heavy isotopic signature, strongly influenced by clay formation. b) The other component, with higher solute flux and lower isotopic signature would result from enhanced mineral dissolution 
rates and less effective clay formation. Such a mechanism is consistent with our observations. According to Dunne (1978), runoff is the dominant variable controlling dissolution rates and water chemistry in this region. When the effective rainfall is high, the leaching of the soils is greater; however the shorter residence time of the water does not allow high concentrations of dissolved elements (including $\mathrm{Si}$ ) to build up in waters. In drier conditions, the residence time of water in the soils increases, and this longer contact time between water and minerals leads to more concentrated solutions. In the meantime, the increased residence time also allows an increased formation of clay minerals with the preferential incorporation of light $\mathrm{Si}$ isotopes, changing the DSi pool to a higher isotopic signature. We therefore argue that the simultaneous increase in DSi concentrations and $\delta^{30} \mathrm{Si}$ signatures in the river can be explained by the fractionation processes outlined above (e.g. based on the relationships between effective rainfall, residence times and water chemistry in the soil). Note that although temperature may also influence weathering, it is not possible to distinguish its relative influence from effective rainfall, as both parameters are strongly linked to the altitude of the sampling site.

Based on pigment data from Bouillon et al. (2009) which suggests that phytoplankton play a minor contribution to the total particulate organic carbon pool, we argue that diatom productivity will therefore have a limited control on $\delta^{30} \mathrm{Si}$ signatures in the headwaters. Furthermore, changes in $\delta^{30} \mathrm{Si}$ caused by weathering processes in the different sub-basins of the river are probably much greater than those derived from diatom uptake. Such situation has been observed previously in the tributaries of the Congo River (Cardinal et al., 2010). As a consequence, if we consider the measured isotopic signatures to be mainly driven by clay formation, then a more important incorporation of Si in clay minerals, and the subsequent increase of $\delta^{30} \mathrm{Si}$ signatures, should be reflected by a change in the dissolved $\mathrm{Si} / \mathrm{LC}^{+*}$ ratio (with $\Sigma \mathrm{C}^{+*}$ being the sum of the major cations corrected for the input of atmospheric salts) relative to the Si source (rock). This ratio would thereby reflect the percentage of Si released by chemical weathering that is incorporated in neoformed clays. This relationship is presented in Fig. 3B. A signature of $-0.25 \pm 0.05 \%$ o in the source rocks was considered as a reasonable approximation given that the Tana Basin drains mainly basaltic volcanic suites from the East African Rift composed of felsic differentiated products. The Si isotopic signature of this geology is probably very similar to those of basalts from the Afar Rift Zone ( $-0.29 \%$; Savage et al., 2011), and their trachytic differentiated liquids $\left(-0.25 \% \circ<\delta^{30} \mathrm{Si}<-0.20 \%\right.$; Savage et al., 2011). The molar Si/ $\Sigma \mathrm{C}^{+}$ratio of the $\mathrm{Si}$ source (2.43) is alleged from the chemical composition of a local quaternary trachyphonolite (King and Chapman, 1972), however the true chemical composition of the source is likely to vary slightly for the different rivers depending e.g. on the proportion of each type of rock upstream each sampling site (King and Chapman, 1972). Fig. 3B shows that the $\delta^{30} \mathrm{Si}$ and $\mathrm{Si} / \mathrm{\Sigma C}^{+*}$ ratios do indeed follow a linear trend, which is consistent with an evolution from a common Si source. A quantitative estimation of Si removal from solution by clay formation, using the method developed by Georg et al. (2007), is unfortunately not possible here as the fraction of cations incorporated into secondary clays is unknown. Such methodological calculations are also complicated by the slight variability of the $\mathrm{Si} / \mathrm{LC}^{+}$ratio in the rock sources within each catchment. Similarly, the influence of DSi uptake by plants cannot be quantified here. However, such effects are probably minimal given that DSi from the different streams seems to derive from a common Si source: The DSi in streams would either directly derive from weathering of primary minerals - as suggested by Ziegler et al. (2005b) for Puerto Rican streams - or from the dissolution of plants phytoliths in soil, with this latter process being at steady-state with Si uptake by plants and not able to therefore significantly impact the DSi concentration and the $\delta^{30} \mathrm{Si}$ composition of the river waters. Such examples have been highlighted in some tributaries of the Congo River (Cardinal et al., 2010). Finally, the potential impact of secondary hydrous sodium silicates and zeolites, formed in such high evaporation conditions and DSi rich environments (Sebag et al., 2001), is also unknown.

We will now compare the $\delta^{30} \mathrm{Si}$ signatures in the headwaters with those published by Alleman et al. (2005) for Lake Tanganyika tributaries, also located in the East African Rift (ca. $1000 \mathrm{~km}$ southeastwards). In order to make a proper comparison, a correction must be applied to take into account the difference in the crystalline rock composition between the two areas. The rivers studied by Alleman et al. (2005) mostly drain rocks of felsic magmatic origin, which therefore have a likely $\delta^{30} \mathrm{Si}$ signature close to $-0.07 \%$ (André et al., 2006), while we estimated the rock signature in the Tana Basin to be of $-0.25 \pm 0.05 \%$. Fig. 5 shows that, once normalized for a source at $0 \%$, the two sets of data cover a similar range of $\delta^{30} \mathrm{Si}$ ratios but different ranges of DSi concentrations. Beyond the possible DSi concentration changes, resulting from dilution and evaporation, this probably reflects a higher weathering rate in the Tana Basin. It is therefore interesting to see that this higher weathering rate does not lead to higher isotopic ratios here.

\subsection{Impact of the dams}

As already noted by Bouillon et al. (2009), the DSi concentration decreased by $41 \%$ (from $364 \mu \mathrm{M}$ to $215 \mu \mathrm{M}$ ) between the Sagana River, which provides $90 \%$ of the water input to the Masinga reservoir, and the Tana River just downstream the reservoir. This dramatic drop of the DSi concentration in the Masinga reservoir was accompanied by a significant increase of the $\delta^{30} \mathrm{Si}$ signature $(+0.54 \%)$, which is consistent with DSi uptake by diatoms. Assuming that the Sagana River is representative of the inputs to the reservoir, we can then use the measured pre- and post Masinga $\delta^{30} \mathrm{Si}$ signatures to model the uptake of the DSi in the system. Two models are generally used to describe the evolution of a stable isotope reservoir. The Rayleigh model describes a closed system, wherein the product (BSi) does not exchange anymore with the reservoir (DSi), while the steady-state model describes an open system at an isotopic equilibrium between the product (BSi) and the reservoir (DSi) (Fry, 2006). According to these two models, the calculated remaining fraction of DSi in the waters after the dam (i.e. the fraction of the DSi reservoir not consumed), $f_{\mathrm{Si}}$, is described as:

$$
\begin{aligned}
& f_{\text {Si Steady-state }}=1+\frac{\delta^{30} \mathrm{Si}-\delta^{30} \mathrm{Si}_{0}}{30} \varepsilon \\
& f_{\text {Si Rayleigh }}=e^{\left(\frac{\delta^{30} \mathrm{Si}^{30} \mathrm{~S}_{\mathrm{i}}}{30^{2}}\right)}
\end{aligned}
$$

where $\delta^{30} \mathrm{Si}_{0}$ is the isotopic signature of the water entering the reservoir (i.e. Sagana River signature), $\delta^{30} \mathrm{Si}$ is the isotopic signature of the

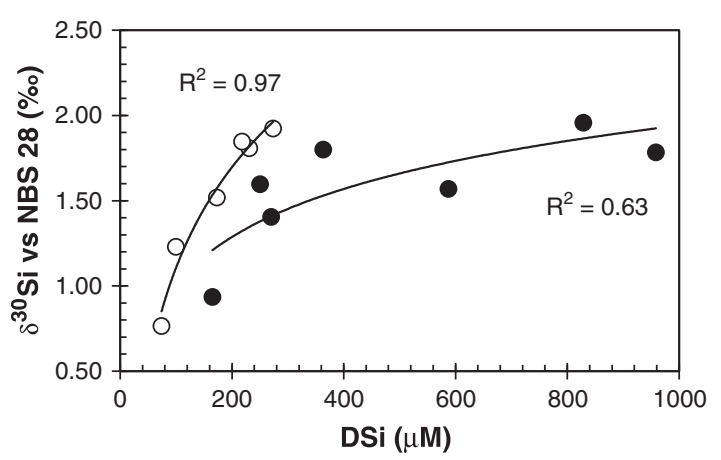

Fig. 5. Comparison between the isotopic signature in the Tana headwaters (black circles) and in the Tanganyika Lake tributaries (empty circles; data from Alleman et al., 2005) after normalization of the isotopic signatures of both basins for the drained rocks $(-0.07 \%$ and $-0.25 \%$ in the Tanganyika and the Tana Basins, respectively). 
water after uptake (i.e. downstream of the dam), and ${ }^{30} \varepsilon$ is the fractionation factor for diatom uptake. Here we will use the ${ }^{30} \varepsilon$ of $-1.1 \pm 0.4 \%$ 。 estimated by Alleman et al. (2005) in Lake Tanganyika (recalculated as ${ }^{30} \varepsilon={ }^{29} \varepsilon \times 1.96$ assuming kinetic mass fractionation law) as it is the only fractionation factor obtained from continental diatoms, while not significantly different from the mean value of $-1.2 \pm 0.5 \%$ found for marine diatoms (see synthesis from Fripiat et al. (2011)).

The Rayleigh model produces data very close to the sampled data here (Fig. 6), with a calculated post-dam water DSi fraction of $f_{\text {Si Rayleigh }}=0.61 \pm 0.15\left( \pm 2 \sigma_{\mathrm{SD}}\right)$, very close to the $f_{\mathrm{Si}}=0.59 \pm 0.06$ calculated solely from the DSi concentration measurements. However the open model values $\left(f_{\text {Si Steady-state }}\right.$ is $\left.0.50 \pm 0.22\right)$ are also similar, so that it is difficult to ascertain which of the two models is operating in the Tana River system. The same conclusions apply to the surface water of the reservoir for which the $f_{\mathrm{Si} \text { Rayleigh }}\left(0.54 \pm 0.14 ; \pm 2 \sigma_{\mathrm{SD}}\right)$ is close to the $f_{\mathrm{Si}}(0.57 \pm 0.06)$ calculated from the DSi concentration, but for which a steady state fractionation cannot be statistically excluded $\left(f_{\text {Si Steady-state }}=0.38 \pm 0.23\right.$ ). One consideration however, is that the 3 month residence time of the reservoir may also induce a bias that cannot be taken into account since we do not know the variability of the inputs to the reservoir within the previous months. But the effects of dams on the DSi isotopic signature exported downstream, to the estuary, are however not negligible although they are dampened by the inputs of other tributaries downstream the dams. Our study therefore clearly shows a significant anthropogenic impact via dams on the riverine $\delta^{30} \mathrm{Si}$ signatures.

\subsection{Estuary}

The DSi concentration and the $\delta^{30} \mathrm{Si}$ composition of most downstream (post-dam) samples from the Tana River which were collected in 2008 and freshwater samples collected in 2004 are quite similar (305 $\mu \mathrm{M}$ and $349 \mu \mathrm{M}$, respectively). This is despite the 4 years of sampling delay and the fact that samples were collected at different periods of the year. Nevertheless, samples collected in February 2004 have both a higher DSi content and a heavier $\delta^{30} \mathrm{Si}$ composition, which is also consistent with our observations in the headwater regions of the River Tana. In the estuary itself, the DSi concentrations seem to follow a simple mixing line between freshwater and seawater as shown by the linear relationship between DSi concentration and salinity (Fig. 4A). This should be indicative of the absence of processes affecting the Si cycle in this estuarine environment, or of a close balance between DSi uptake and release. However, this latter hypothesis seems unlikely as no significant change occurs in the $\delta^{30} \mathrm{Si}$ signature along the salinity gradient we studied. In samples E-23 and E-24, where DSi

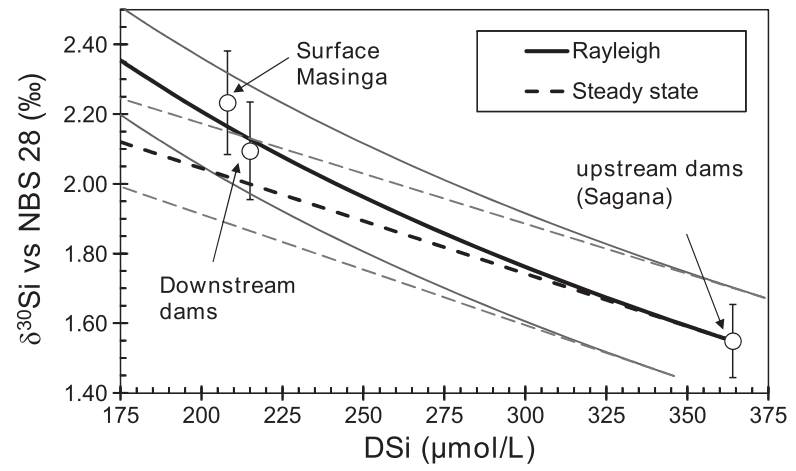

Fig. 6. Evolution of the DSi concentration and isotopic signature from the Sagana River (main inflow to the Masinga Reservoir), the surface water of the reservoir and the water downstream the dams. Dashed line indicate the theoretical evolution of the system based on a steady-state model and assuming a fractionation factor of $-1.1 \%$, while solid line present the evolution based on a Rayleigh model. Thin lines indicate the maximum error bar based on the Sagana measurement $\left(2 \sigma_{\mathrm{SD}}\right.$ on the $\delta^{30} \mathrm{Si}$ ratio and $5 \%$ on the DSi concentration measurements). The system seems to follow a Rayleigh model, but a steady-state model can however not be totally excluded. concentrations were slightly different from those expected from the mixing line (Fig. 4A), the $\delta^{30} \mathrm{Si}$ signatures are not significantly different and these DSi concentrations might simply reflect local artifacts. If no processes affect the DSi in the estuary, then the $\delta^{30} \mathrm{Si}$ ratio should also follow a mixing line between the signatures of the two end-members: the freshwater $(+2.05 \%$ ) and the local coastal marine signature, but as no marine sample was taken this latter value is unknown. Due to the high DSi concentration in the river relative to the ocean, a significant shift in the conservative isotopic mixing curve is expected only at high salinity, but sampling is here limited to a salinity of 28.8 while regional seawater has a salinity of 35.2. We will therefore not draw conclusions on the whole mixing process. However, these results show that no hidden process affects the DSi - and thereby its isotopic signature - in most of the estuary and that it appears to be a region of low diatom productivity where DSi behaves conservatively during the mixing with seawater. Abiotic processes like reverse weathering do not seem to affect the DSi fluxes and neither does the increased BSi dissolution due to lower DSi concentration and higher ionic concentration (Uliana et al., 2001).

\section{Conclusion}

By studying, from headwaters to mouth, the evolution of $\delta^{30} \mathrm{Si}$ signatures of DSi in the Tana River basin, this study has provided valuable insights. The distribution of DSi and the isotopic signatures of Si were shown to be affected by a succession of distinct, spatially separated, processes acting at different locations along the flow path.

In the headwaters of the Tana watershed, the main factor for isotopic fractionation seems to be weathering, with a possible important influence of soil drainage. Dams have a strong effect on the dissolved $\mathrm{Si}$, reducing its concentration by $\sim 40 \%$ (at the time of sampling in 2008), and inducing an increase of the $\delta^{30} \mathrm{Si}$ signature of $+0.54 \%$, which is consistent with a significant uptake of DSi by diatoms within the reservoir. This anthropogenically induced reduction in DSi and its isotopic imprint is then maintained down to the river mouth and thereby impacts the isotopic composition of continental Si supply to the ocean. Due to the increasing construction of dams on a global scale, this might have a significant impact on the seawater Si signatures, at least for semi-enclosed seas (e.g., Humborg et al., 2008 for the Baltic Sea, Ludwig et al., 2009 for the Mediterranean Basin). In the estuary, no significant isotopic fractionation is observed along the studied salinity gradient, indicating the absence of processes affecting the DSi.

\section{Acknowledgments}

The authors thank N. Mattielli and J. de Jong (Université Libre de Bruxelles) for the management of the NuPlasma facility, which has been funded by the Fonds de la Recherche Scientifique (FRFC 2.4.512.00F). L. Monin, J. Navez and A. Silinski are thanked for lab assistance and artwork. We would like to thank V. Panizzo for English corrections. This work has been funded by the Belgian Science Policy Office (BELSPO), through an Action 1 (MO/37/013) supporting $\mathrm{HH}$ and DC. Financial support for fieldwork was provided by two travel grants to S.B. by the FWO-Vlaanderen. Michael Korntheuer and Gabriel Kung $u$ provided assistance in the field during fieldwork in the estuary and throughout the Tana basin, respectively.

\section{References}

Abraham, K., Opfergelt, S., Fripiat, F., Cavagna, A.J., de Jong, J., Foley, S.F., André, L., Cardinal, D., 2008. ${ }^{30} \mathrm{Si}$ and ${ }^{29} \mathrm{Si}$ determinations on USGS BHVO-1 and BHVO-2 reference materials with a new configuration on a Nu plasma multi-collector ICP-MS. Geostandards and Geoanalytical Research 32, 193-202.

Alleman, L.Y., Cardinal, D., Cocquyt, C., Plisnier, P.-D., Descy, J.P., Kimirei, I., Sinyinza, D., André, L., 2005. Silicon isotopic fractionation in Lake Tanganyika and its main tributaries. Journal of Great Lakes Research 31, 509-519. 
André, L., Cardinal, D., Alleman, L.Y., Moorbath, S., 2006. Silicon isotopes in 3.8 Ga West Greenland rocks as clues to the Eoarchaean supracrustal Si cycle. Earth and Planetary Science Letters 245 (1-2), 162-173.

Baker, B.H., 1967. Geology of the Mount Kenya area. Geological Survey of Kenya Report no. 79, Nairobi.

Berner, R.A., 1997. The rise of plants and their effect on weathering and atmospheric $\mathrm{CO}_{2}$. Science 276, 544-546.

Beusen, A.H.W., Bouwman, A.F., Dürr, H.H., Dekkers, A.L.M., Hartmann, J., 2009. Globa patterns of dissolved silica export to the coastal zone: results from a spatially explicit global model. Global Biogeochemical Cycles 23, GB0A02.

Bluth, G.J.S., Kump, L.R., 1994. Lithologic and climatologic controls of river chemistry. Geochimica et Cosmochimica Acta 58, 2341-2359.

Bouillon, S., Dehairs, F., Schiettecatte, L.S., Borges, A.V., 2007. Biogeochemistry of the Tana estuary and delta (northern Kenya). Limnology and Oceanography 52, 46-59.

Bouillon, S., Abril, G., Borges, A.V., Dehairs, F., Govers, G., Hughes, H.J., Merckx, R Meysman, F.J.R., Nyunja, J., Osburn, C., Middelburg, J.J., 2009. Distribution, origin and cycling of carbon in the Tana River (Kenya): a dry season basin-scale survey from headwaters to the delta. Biogeosciences 6, 2475-2493.

Brown, T., Schneider, H., Harper, D., 1996. Multi-scale estimates of erosion and sediment yields in the Upper Tana basin, Kenya. IAHS Publications-Series of Proceedings and Reports-Intern Assoc Hydrological Sciences, 236, pp. 49-54.

Cardinal, D., Alleman, L.Y., Jong, J.D., Ziegler, K., André, L., 2003. Isotopic composition of silicon measured by multicollector plasma source mass spectrometry in dry plasma mode. Journal of Analytical Atomic Spectrometry 18, 213-218.

Cardinal, D., Gaillardet, J., Hughes, H.J., Opfergelt, S., André, L., 2010. Contrasting silicon isotope signatures in rivers from the Congo Basin and the specific behaviour of organic-rich waters. Geophys Research Letters 37, L12403.

Conley, D.J., Stålnacke, P., Pitkänen, H., Wilander, A., 2000. The transport and retention of dissolved silicate by rivers in Sweden and Finland. Limnology and Oceanography $45,1850-1853$

Conley, D.J., Likens, G.E., Buso, D.C., Saccone, L., Bailey, S.W., Johnson, C.E., 2008. Deforestation causes increased dissolved silicate losses in the Hubbard Brook Experimental Forest. Global Change Biology 14, 2548-2554.

Cornelis, J.-T., Delvaux, B., Georg, R.B., Lucas, Y., Ranger, J., Opfergelt, S., 2011. Tracing the origin of dissolved silicon transferred from various soil-plant systems towards rivers: a review. Biogeosciences 8, 89-112.

De La Rocha, C.L., Brzezinski, M.A., DeNiro, M.J., 1996. Purification, recovery, and laserdriven fluorination of silicon from dissolved and particulate silica for the measurement of natural stable isotope abundances. Analytical Chemistry 68, 3746-3750.

De La Rocha, C.L., Brzezinski, M.A., DeNiro, M.J., 1997. Fractionation of silicon isotopes by marine diatoms during biogenic silica formation. Geochimica et Cosmochimica Acta 61, 5051-5056.

De La Rocha, C.L., Brzezinski, M.A., DeNiro, M.J., 2000. A first look at the distribution of the stable isotopes of silicon in natural waters. Geochimica et Cosmochimica Acta 64 (14), 2467-2477.

Delstanche, S., Opfergelt, S., Cardinal, D., Elsass, F., André, L., Delvaux, B., 2009. Silicon isotopic fractionation during adsorption of aqueous monosilicic acid onto iron oxide. Geochimica et Cosmochimica Acta 73, 923-934.

Dessert, C., Dupre, B., Gaillardet, J., Francois, L.M., Allegre, C.J., 2003. Basalt weathering laws and the impact of basalt weathering on the global carbon cycle. Chemical Geology 202, 257-273.

Ding, T., Jiang, S., Wan, D., Li, Y., Li, J., Song, H., Liu, Z., Yao, X., 1996. Silicon Isotope Geochemistry. Geological Publishing House, Beijing, China.

Ding, T., Wan, D., Wang, C., Zhang, F., 2004. Silicon isotope compositions of dissolved and suspended matter in the Yangtze. Geochimica et Cosmochimica Acta 68, 205-216.

Ding, T., Ma, G., Shui, M., Wan, D., Li, R., 2005. Silicon isotope study on rice plants from the Zhejiang province. China Chemical Geology 218, 41-50.

Ding, T., Zhou, J., Wan, D., Chen, Z., Wang, C., Zhang, F., 2008. Silicon isotope fractionation in bamboo and its significance to the biogeochemical cycle of silicon. Geochimica et Cosmochimica Acta 72, 1381-1395.

Dunne, T., 1978. Rates of chemical denudation of silicate rocks in tropical catchments. Nature 274, 244-246.

Dunne, T., 1979. Sediment yield and land use in tropical catchments. Journal of Hydrology $42,281-300$

Fripiat, F., Cavagna, A.-J., Savoye, N., Dehairs, F., André, L., Cardinal, D., 2011. Isotopic constraints on the Si-biogeochemical cycle of the Antarctic Zone in the Kerguelen area (KEOPS). Marine Chemistry 123, 11-22

Fry, B., 2006. Stable Isotope Ecology, third ed. Springer Verlag, New York

Garnier, J., Sferratore, A., Meybeck, M., Billen, G., Dürr, H., 2006. Modeling silicon transfer processes in river catchments. In: Ittekkot, V., Unger, D., Humborg, C., Tac An, N (Eds.), The Silicon Cycle: Human Perturbations and Impacts on Aquatic Systems. Island Press, Washington, pp. 139-162.

Georg, R.B., Reynolds, B.C., Frank, M., Halliday, A.N., 2006. Mechanisms controlling the silicon isotopic compositions of river waters. Earth and Planetary Science Letters 249, 290-306

Georg, R.B., Reynolds, B.C., West, A.J., Burton, K.W., Halliday, A.N., 2007. Silicon isotope variations accompanying basalt weathering in Iceland. Earth and Planetary Science Letters 261, 476-490.

Georg, R.B., Zhu, C., Reynolds, B.C., Halliday, A.N., 2009. Stable silicon isotopes of groundwater, feldspars, and clay coatings in the Navajo Sandstone aquifer, Black Mesa, Arizona, USA. Geochimica et Cosmochimica Acta 73, 2229-2241.

Grieser, J., Gommes, R., Bernardi, M., 2006. New LocClim - the local climate estimator of FAO. Geophysical Research Abstracts 8, 08305.
Hodson, M.J., Parker, A.G., Leng, M.J., Sloane, H.J., 2008. Silicon, oxygen and carbon isotope composition of wheat (Triticum aestivum L.) phytoliths: implications for palaeoecology and archaeology. Journal of Quaternary Science 23, 331-339.

Hughes, F.M.R., 1984. A comment on the impact of development schemes on the floodplain forests of the Tana River of Kenya. The Geographical Journal 150, 230-244.

Hughes, H.J., Sondag, F., Cocquyt, C., Laraque, A., Pandi, A., André, L., Cardinal, D., 2011. Effect of seasonal biogenic silica variations on dissolved silicon fluxes and isotopic signatures in the Congo River. Limnology and Oceanography 56, 551-561.

Humborg, C., Pastuszak, M., Aigars, J., Siegmund, H., Mörth, C.M., Ittekkot, V., 2006. Decreased silica land-sea fluxes through damming in the Baltic Sea catchment significance of particle trapping and hydrological alterations. Biogeochemistry 77, 265-281.

Humborg, C., Smedberg, E., Medina, M.R., Mörth, C.M., 2008. Changes in dissolved silicate loads to the Baltic Sea - the effects of lakes and reservoirs. Journal of Marine Systems 73, 223-235.

King, B.C., Chapman, G.R., 1972. Volcanism of the Kenya rift valley. Philosophical Transactions of the Royal Society A 271, 185-208.

Kitheka, J.U., Obiero, M., Nthenge, P., 2005. River discharge, sediment transport and exchange in the Tana Estuary, Kenya. Estuarine, Coastal and Shelf Science 63, 455-468.

Kump, L.R., Brantley, S.L., Arthur, M.A., 2000. Chemical, weathering, atmospheric $\mathrm{CO}_{2}$, and climate. Annual Review of Earth and Planetary Sciences 28, 611-667.

Laruelle, G.G., Roubeix, V., Sferratore, A., Brodherr, B., Ciuffa, D., Conley, D.J., Dürr, H.H., Garnier, J., Lancelot, C., Phuong, Q.L.T., et al., 2009. Anthropogenic perturbations of the silicon cycle at the global scale: key role of the land-ocean transition. Global Biogeochemical Cycles 23, GB4031.

Ludwig, W., Dumont, E., Meybeck, M., Heussner, S., 2009. River discharges of water and nutrients to the Mediterranean and Black Sea: major drivers for ecosystem changes during past and future decades? Progress in Oceanography 80, 199-217.

Maingi, J.K., Marsh, S.E., 2002. Quantifying hydrologic impacts following dam construction along the Tana River, Kenya. Journal of Arid Environments 50, 53-79.

Opfergelt, S., Cardinal, D., Henriet, C., Draye, X., André, L., Delvaux, B., 2006. Silicon isotopic fractionation by banana (Musa spp.) grown in a continuous nutrient flow device. Plant and Soil 285, 333-345.

Opfergelt, S., Delvaux, B., André, L., Cardinal, D., 2008. Plant silicon isotopic signature might reflect soil weathering degree. Biogeochemistry 91, 163-175.

Opfergelt, S., De Bournonville, G., Cardinal, D., André, L., Delstanche, S., Delvaux, B., 2009. Impact of soil weathering degree on silicon isotopic fractionation during adsorption onto iron oxides in basaltic ash soils, Cameroon. Geochimica et Cosmochimica Acta 73, 7226-7240.

Opfergelt, S., Cardinal, D., André, L., Delvigne, C., Bremond, L., Delvaux, B., 2010. Variations of $\delta^{30} \mathrm{Si}$ and $\mathrm{Ge} / \mathrm{Si}$ with weathering and biogenic input in tropical basaltic ash soils under monoculture. Geochimica et Cosmochimica Acta 74, 225-240.

Pacini, N., Harper, D., Mavuti, K., Brown, T., 1999. Hydrological and ecological considerations in the management of a catchment controlled by a reservoir cascade: the Tana River, Kenya. In: Harper, D., Brown, T. (Eds.), The Sustainable Management of Tropical Catchments. John Wiley \& Sons Ltd., New York, pp. 239-258.

Reynolds, B.C., Aggarwal, J., André, L., Baxter, D., Beucher, C., Brzezinski, M.A., Engström, E., Georg, R.B., Land, M., Leng, M.J., Opfergelt, S., Rodushkin, I., Sloane, H.J., van den Boorn, S.H.J.M., et al., 2007. An inter-laboratory comparison of Si isotope reference materials. Journal of Analytical Atomic Spectrometry 22, 561-568.

Roelandt, C., Goddéris, Y., Bonnet, M.P., Sondag, F., 2010. Coupled modeling of biospheric and chemical weathering processes at the continental scale. Global Biogeochemical Cycles 24, GB2004.

Savage, P.S., Georg, R.B., Armytage, R.M.G., Williams, H.M., Halliday, A.N., 2010. Silicon isotope homogeneity in the mantle. Earth and Planetary Science Letters 295, 139-146.

Savage, P.S., Georg, R.B., Williams, H.M., Burton, K.W., Halliday, A.N., 2011. Silicon isotope fractionation during magmatic differentiation. Geochimica et Cosmochimica Acta 75, 6124-6139.

Schneider, H., Brown, T., Harper, D., 1999. Remote sensing and GIS studies of erosion potential for catchment management: a densely populated agricultural catchment in Kenya. In: Harper, D., Brown, T. (Eds.), The Sustainable Management of Tropical Catchments. John Wiley \& Sons Ltd., New York, pp. 31-47.

Sebag, D., Verrecchia, E.P., Lee, S.J., Durand, A., 2001. The natural hydrous sodium silicates from the northern bank of Lake Chad: occurrence, petrology and genesis. Sedimentary Geology 139, 15-31.

Speck, H., 1982. Soils of the Mount Kenya Area: their formation, ecological, and agricultural significance. Mountain Research and Development 2, 201-221.

Struyf, E., Smis, A., Van Damme, S., Garnier, J., Govers, G., Van Wesemael, B., Conley, D.J., Batelaan, O., Frot, E., Clymans, W., et al., 2010. Historical land use change has lowered terrestrial silica mobilization. Nature Communications 1,129.

Uku, J.N., Mavuti, K.M., 1994. Comparative limnology, species diversity and biomass relationship of zooplankton and phytoplankton in five freshwater lakes in Kenya. Hydrobiologia 272, 251-258.

Uliana, E., Lange, C.B., Donner, B., Wefer, G., 2001. Siliceous phytoplankton productivity in the Congo Basin over the past 460,000 years: marine vs. riverine influence, ODP Site 1077. Proceedings of the Ocean Drilling Program - Scientific Results $175,1-32$.

Ziegler, K., Chadwick, O.A., Brzezinski, M.A., Kelly, E.F., 2005a. Natural variations of $\delta^{30} \mathrm{Si}$ ratios during progressive basalt weathering, Hawaiian Islands. Geochimica et Cosmochimica Acta 69, 4597-4610.

Ziegler, K., Chadwick, O.A., White, A.F., Brzezinski, M.A., 2005b. $\delta^{30}$ Si systematics in a granitic saprolite, Puerto Rico. Geology 33, 817-820. 